\section{ORGDP}

a

OAK RIDGE GASEOUS DIFFUSION PLANT

UNION

CARBIDE

$K / R A-102$

CONTROL OF AIRBORNE NICKEL WELDING FUMES

BY MEANS OF A

VERTICAL LAMINAR AIR FLOW SYSTEM
T. C. HELMS

ORGDP INDUSTRIAL HYGIENE DEPARTMENT

DECEMBER 8,1980

OPERATED BY

UNIDN CARBIDE CORPORATION FOR THE UNITED STATES OEPARTMENT OF ENERGY

\section{MASTER}




\section{DISCLAIMER}

This report was prepared as an account of work sponsored by an agency of the United States Government. Neither the United States Government nor any agency Thereof, nor any of their employees, makes any warranty, express or implied, or assumes any legal liability or responsibility for the accuracy, completeness, or usefulness of any information, apparatus, product, or process disclosed, or represents that its use would not infringe privately owned rights. Reference herein to any specific commercial product, process, or service by trade name, trademark, manufacturer, or otherwise does not necessarily constitute or imply its endorsement, recommendation, or favoring by the United States Government or any agency thereof. The views and opinions of authors expressed herein do not necessarily state or reflect those of the United States Government or any agency thereof. 


\section{DISCLAIMER}

Portions of this document may be illegible in electronic image products. Images are produced from the best available original document. 


\title{
CONTROL OF AIRBORNE NICKEL WELDING FUMES BY MEANS OF A VERTICAL
}

\author{
LAMINAR AIR FLOW SYSTEM
}

For the past few years at the Oak Ridge, Paducah, and Portsmouth Gaseous Diffusion Plants, there has been considerable interest in the exploration of various types of engineering methods to control airborne nickel and other metallic oxides in welding fumes. The purpose of this study was to evaluate the effectiveness of a clean room facility with laminar air flow in the control of nickel fumes released from metal inert gas (MIG) and shielded metal arc (SMA) welding operations performed on mild steel using nickel filler materials. This study is the second phase of a report for a feasibility study of a proposed FY 1982 Line Item Project entitied "Reduction of Airborne Metals, Phase I" submitted to DOE in 1979 and subsequently tabled for further research. The Phase I study has focused on controlling airborne nickel levels to $0.100 \mathrm{mg} / \mathrm{m}^{3}$, which was considered to be the lowest practical level achievable using conventional local exhaust ventilation systems. Based on the possibility that the final promulgated OSHA nickel standard may limit airborne exposures to as low as $0.015 \mathrm{mg} / \mathrm{m}^{3}$, it was necessary to explore nonconventional control methods, such as a vertical laminar air flow clean room to meet these requirements. In order for such a system to be successful, it would not only have to meet the criteria for fume capture and removal, but its design should avoid disruption of the protective shielding gases which could result in poor weld quality. Fortunately for this study, the services of an existing clean room facility, which had most of the desired characteristics, was obtained for a period of about four weeks for sampling purposes. The clean room is located in Building 9202 at Y-12 and was formerly used in conjunction with the NASA space program. The facility was designed to control airborne extraneous dust particles or bacteria by means of a laminar air flow system which operated at about 60 feet per minute. A double panel of high efficiency particulate air or HEPA filters provided the necessary removal of unwanted airborne substances from entering the clean room atmosphere.

Based on preliminary smoke generation studies and ventilation measurements, along with some actual welding tests, it was found that the maximum airflow of the original design was insufficient to control welding fumes satisfactorily. The dimensions of the room were about 20 by 20 feet square and about 10 feet high. Welding curtains were installed from floor to ceiling to create an area approximately 8 feet by 8 feet square and about 10 feet high in order to narrow the area

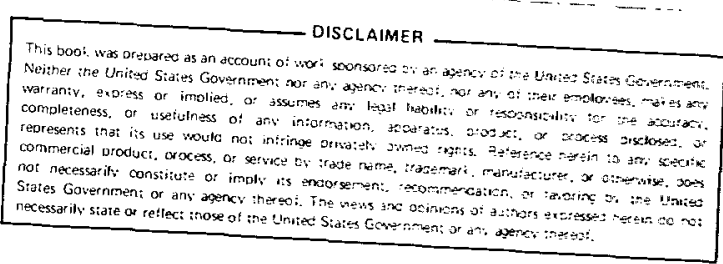

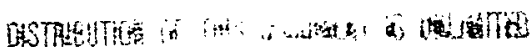


of the room and increase air velocity. Sheet metal was installed over the remaining floor area and an additional barrier was placed over the ceiling of the room such that the total airflow was channeled into the area bordered by the welding curtains. Change in the airflow velocity was accomplished by either closing or opening baffles located in the duct work leading to the HEPA filter system prior to its entrance into the reduced clean room area. Two types of sampling pumps, the DuPont constant flow Model P-2400 calibrated at 2.0 liters per minute and the Radeco Model HD-28 high volume "gooseneck" pump calibrated at 6.0 liters per minute were connected to 37 millimeter and 47 millimeter filter cassettes, respectively, with 0.8 micron pore size filters. Two of the DuPont pumps were worn by the welder for sampling both inside and outside the welding helmet. The remainder of the low flow pumps were used as area samples placed in and around the welding site. The two high volume "gooseneck" pumps were positioned at either end of the welding table at approximately the height of the breathing zone of the welder. The high volume pumps were primarily used to obtain adequate sampling volume so that detection of low airborne concentrations of nickel could be assured.

Sample analysis was conducted by the ORGDP Analytical Technology Department through means of atomic absorption spectroscopy. The graphite furnace or flameless atomic absorption method was used for samples expected to contain less than 1.0 microgram total while conventional flame atomic absorption spectroscopy was used in analys is of samples which were expected to be greater than 1.0 microgram total for nickel. Prior to submission of the field samples, four levels of spiked nickel samples of $10,1,0.3$, and 0.03 total micrograms of nickel were prepared and submitted to the laboratory personnel to evaluate the lower detectable limits for the flame and flameless atomic absorption methods. All of the glassware used was washed in 50 percent nitric acid and then rinsed at least three times with distilled deionized water. Upon the collection of samples and submission to the laboratory, blank filter cassettes and spiked nickel samples were submitted along with field samples for comparison of results. It was found that the graphite furnace or flameless atomic absorption unit theoretically had a minimum detectable level of 0.03 total micrograms of nickel on the filter paper. In order to compute a minimum sampling duration at a flow rate of 2.01 iters per minute, the following formula was used:

$\underset{\text { PER SAMPLE }}{\text { MINIMUM DURATION }}=\frac{10 \times \text { analytical sensitivity }}{T L V \times \text { Flowrate }}=\frac{0.03 \mu \mathrm{g} \mathrm{Ni} \times 10}{0.015 \mathrm{mg} / \mathrm{m}^{3} \times 27 \mathrm{pm}} \times 1000=10 \mathrm{M}$

A sampling time of at least 10 minutes was theoretically needed to detect one-tenth of the proposed $0.015 \mathrm{mg} / \mathrm{m}^{3}$ TLV. However, actual sampling times were extended to approximately 25 minutes per session to assure quantities of sample equal to or beyond the minimum detectable limits. 
Approximately 15 minutes of setup time was allowed between samples in order to change filters, prepare welding materials for the next sampling sequence, and to readjust the ventilation of the room to obtain the proper air flow. The clean room facility was visited daily for a period of four weeks or approximately 20 sampling periods with approximately three sampling periods per day. Breathing zone samples were collected inside a modified welder's helmet such that the filter cassette was directly at the breathing zone of the welder. The shielded metal arc welding was conducted primarily using a nickel 141 filter rod with welding being conducted in a $3 G$ or vertical position for welding on four inch by eight inch plates or "coupons" tack welded together in the center. The metal inert gas welding was conducted in a similar manner using .045-inch diameter nickel filler wire with a current ranging from 275 to 325 amperes and about 25 to 30 volts. In addition to flat plate welding, two large geometric models, designed to simulate field welding conditions, were studied to evaluate welding fume control under conditions of interrupted laminar airflow patterns. These geometric shapes included a large "tin can" shaped cylinder sealed at one end 30 inches in diameter and 4 feet in length. SMA welding was performed approximately 18 inches inside the cylinder, while MIG welding was conducted about 6 inches inside the cylinder. Another geometric shape, designed to simulate flange welding on a large converter unit, consisted of a large "doughnut" shaped flat circular plate with a hole in the center to which was attached a 12-inch flange.

Sample results have been summarized and are listed in Tables $1,2,3$, and 4. The data generally indicate a decrease in airborne nickel levels with an increase in air velocity. For example, MIG plate welding in Table 2 showed that outside the welder's helmet, $\mathrm{mg} / \mathrm{m}^{3}$ levels ranged from $2.409,0.654,0.373,0.060,0.011$ and 0.001 for air flows of $20,75,95,160,170$, and 240 feet per minute, respectively. With the exception of an occasional unexpected data point, the overall pattern of lower airborne concentrations for higher air velocities was consistent. This trend was also apparent in the area sampling data presented in Tables 3 and 4. Personnel sampling data have been graphed with airborne concentrations plotted versus air flow in feet per minute (Figures $1-6$ ).

Prior to graphing, the personnel data were examined to determine the correlation, if any, between air flow and milligrams per cubic meter of nickel. This was accomplished by using a Hewlett-Packard Model 67 programmable calculator plus a prerecorded magnetic card for curve fitting. The coefficient of determination $\underline{r}^{2}$, which indicates the quality of fit achieved by the regression, was used as criterion. That is, values of $r^{2}$ close to 1.00 (perfect correlation) indicate a better fit than values close to zero (no correlation). Following the input of data pairs for each welding category, it was found that an exponential curve with 
mathematical formula $y=a e^{b x},(a>0)$, best described the data. The regression coeffjcients, " $a$ " and " $b$ " define the curve generated, $A$ summary of the $r^{2}$ valves is listed in Table 5. Results show $r^{2}$ values greater than $0 . \overline{5} 86$ for all categories with the exception of SMA $\bar{A}$ geometric donut shape welding outside the helmet. In fact, all but one of the MIG welding types exceeded 0.918 , indicating a very close curve fit. Although the values for SMA welding types were acceptable, one possible explanation may account for the less than expected closeness of fit. In general, SMA welding procedures resulted in lesser amounts of fume generated and collected, which required laboratory analyses at levels approaching lower detectable limits. Consequently, any small error in analytical technique could result in a significant change in $r^{2}$ values. An example of such possible case can be illustrated in Figure 1 for SMA plate welding. Ten of the data points for inside and outside the helmet are $0.015 \mathrm{mg} / \mathrm{m}^{3}$ or less. Any variation in sample results can significantly affect curve slope and $r^{2}$ values at these low concentrations. One attractive feature of the curve graphing is that it enables the prediction of airflow levels necessary to control to $0.015 \mathrm{mg} / \mathrm{m}^{3}$ by simply finding the point of intersection with the corresponding airflow on the graph.

As is seen in Table 5, theoretical airflows ranged from $120 \mathrm{fpm}$ for SMA plate welding inside the helmet to a maximum of $270 \mathrm{fpm}$ for the SMA Geometric Donut Shape outside the helmet. Values for MIG ranged from a low of $165 \mathrm{fpm}$ for plate welding inside the helmet to an offscale reading for geometric donut shapes outside the helmet. The graphs indicate that a minimum of 120 to 165 feet per minute air velocity is needed to control nickel oxide fumes to a level of $0.015 \mathrm{mg} / \mathrm{m}^{3}$ inside the helmet during tabletop plate welding operations. However, these airflow levels may not be sufficient for welding on geometric shapes, where flows approaching 200 feet per minute may be required.

From data observed in these experiments, it appears that the laminar flow clean room approach to controlling welding fumes can be successful in certain small table top welding operations. However, almost any interferences that obstruct the downward airflow can result in eddy currents and subsequent build-up of fumes by entrapment.

Thus, airflow patterns differ significantly when comparing table top operations to welding on large cylindrical and/or doughnut shaped items. With a doughnut shaped prototype, which was positioned parallel to and approximately 40 inches above the floor, airflow was forced around the circumference of the shape as well as directly through the center opening of the flange or "doughnut" hole. The airflow patterns differed dramatically from those encountered with the 30-inch diameter, large cylindrical shapes in which the airflow had little effect upon fumes which accumulated within the cylinder itself. Fumes entrapped inside the cylinder would tend to build up to a level at which overflow into the downward air current would eventually occur, but only after traveling about 2 feet from the outer edge of the cylinder itself. 
This study illustrates some of the problems encountered in welding fume sampling. Any number of variables can dramatically effect nickel conditions inside and outside the helmet, including such things as welder position, the amount of current used and speed of welding, the amount of preparation performed in between welds, and of course the airflow currents themselves. Generally, it was found that as long as the welding plume could be kept from the breathing zone of the welder, concentrations inside the welding helmet did not exceed the $0.015 \mathrm{mg} / \mathrm{m}^{3}$ level. If the piume at any time was able to reach the breathing zone of the welder, such encounters would almost always result in airborne nickel concentrations in excess of $0.015 \mathrm{mg} / \mathrm{m}^{3}$. One additional experiment was conducted to test the effectiveness of a Bernard attachment to a shielded welding gun. Results from the Bernard system indicated that such a system by itself was not effective in reducing airborne nickel concentrations to the $0.015 \mathrm{mg} / \mathrm{m}^{3}$ level. For example, laminar airflow levels of 180 feet per minute, with the Bernard system,operating, resulted in $0.050 \mathrm{mg} / \mathrm{m}^{3}$ inside the helmet and $0.021 \mathrm{mg} / \mathrm{m}^{3}$ outside the helmet. With the airflow turned off, the nickel concentrations inside the helmet were $0.387 \mathrm{mg} / \mathrm{m}^{3}$ outside the helmet they were $0.563 \mathrm{mg} / \mathrm{m}^{3}$. Only when airflow levels approached the 250 feet per minute were concentrations achieved below $0.015 \mathrm{mg} / \mathrm{m}^{3}$. These results seem to indicate that the Bernard system alone is not effective in reducing airborne nickel levels to the $0.015 \mathrm{mg} / \mathrm{m}^{3} \mathrm{stage}$.

In conclusion, it was found that the use of a laminar flow clean room method for welding fume control is certainly a very specialized method which could be very expensive and may at times be impractical to implement in an actual field situation. As stated at the beginning, the purpose of the clean room with the laminar flow was to look at what would be considered to be, theoretically, the ultimate technology available to control airborne nickel to meet a 15 micrograms per cubic meter standard, should such a level be adopted in the future by OSHA. One of the biggest problems encountered with the laminar airflow system was the reduced efficiency of the airflow due to the clogging of the high efficiency particulate air filter with the welding fume particles and dust. At the beginning of the experimentation, it was possible to achieve maximum airflow levels of around 250 to 300 feet per minute. However, after only 15 workdays of sampling, the airflow was reduced to about 140-150 feet per minute maximum within the room. For such a system as a laminar flow clean room to work efficiently and effectively in an actual shop situation, bag houses or other prefiltering units may have to be incorporated into the system so that the relatively expensive HEPA filters would last long enough to make them more cost effective. Finally, based on a restricted time frame of four weeks to complete sampling, only preliminary conclusions can be drawn from the somewhat limited number of samples collected. To be more conclusive, such a 
study should be conducted in an actual weld shop or field environment with full-scale geometric shapes being welded under typical shop conditions. Such a "pilot plant" model would give much more insight into the effectiveness and of the feasibility of such a laminar flow system functioning under day-to-day work activities. 
Table 1

SHIELDED METAL ARC (SMA)

PERSONNEL SAMPLES-INSIDE AND OUTSIDE HELMET

\begin{tabular}{|c|c|c|c|c|c|c|c|c|}
\hline \multicolumn{3}{|c|}{ PLATE WELDING } & \multicolumn{3}{|c|}{ GEOMETRIC "DONUT" SHAPE } & \multicolumn{3}{|c|}{ GEOMETRIC CYLINDER "TIN CAN" } \\
\hline \multirow{2}{*}{$\begin{array}{c}\text { AIR FLOW } \\
\text { (fpm) }\end{array}$} & \multicolumn{2}{|c|}{$\mathrm{mg} / \mathrm{m}^{3}$ OF NICKEL } & \multirow{2}{*}{$\begin{array}{c}\text { AIR FLOW } \\
\text { (fpm) }\end{array}$} & \multicolumn{2}{|c|}{$\mathrm{mg} / \mathrm{m}^{3}$ OF NICKEL } & \multirow{2}{*}{$\begin{array}{c}\text { AIR FLOW } \\
\text { (fpm) }\end{array}$} & \multicolumn{2}{|c|}{$\mathrm{mg} / \mathrm{m}^{3}$ OF NICKEL } \\
\hline & INSIDE & OUTSIDE & & INSIDE & OUTSIDE & & INSIDE & OUTSIDE \\
\hline 75 & .050 & .083 & $20^{*}$ & .736 & .918 & 63 & 5.468 & 5.842 \\
\hline 100 & .006 & .038 & 85 & .094 & 1.059 & 90 & 1.002 & .785 \\
\hline 160 & .015 & .009 & 90 & .021 & .644 & 110 & .634 & .115 \\
\hline 175 & .004 & .006 & 110 & .065 & .015 & $145+$ & .007 & .128 \\
\hline 185 & .010 & .022 & 115 & .014 & .197 & & & \\
\hline 200 & .007 & .034 & 160 & .002 & .122 & & & \\
\hline 230 & .004 & $<.001$ & 250 & .003 & .025 & & & \\
\hline 300 & $<.001$ & $<.001$ & & & & & & \\
\hline
\end{tabular}

Table 2

METAL INERT GAS (MIG)

PERSONNEL SAMPLES-INSIDE AND OUTSIDE HELMET

\begin{tabular}{|c|c|c|c|c|c|c|c|c|}
\hline \multicolumn{3}{|c|}{ PLATE WELDING } & \multicolumn{3}{|c|}{ GEOMETRIC "DONUT" SHAPE } & \multicolumn{3}{|c|}{ GEOMETRIC CYLINDER "TIN CAN" } \\
\hline \multirow{2}{*}{$\begin{array}{l}\text { AIR FLOW } \\
\text { (fpm) }\end{array}$} & \multicolumn{2}{|c|}{$\mathrm{mg} / \mathrm{m}^{3}$ OF NICKEL } & \multirow{2}{*}{$\begin{array}{l}\text { AIR FLOW } \\
(f p m)\end{array}$} & \multicolumn{2}{|c|}{$\mathrm{mg} / \mathrm{m}^{3}$ OF NICKEL } & \multirow{2}{*}{$\begin{array}{c}\text { AIR FLOW } \\
\text { (fpm) }\end{array}$} & \multicolumn{2}{|c|}{$\mathrm{mg} / \mathrm{m}^{3}$ OF NICKEL } \\
\hline & INSIDE & OUTSIDE & & INSIDE & OUTSIDE & & INSIDE & OUTSIDE \\
\hline $20^{*}$ & 3.214 & 2.409 & 20 & 3.391 & 2.916 & 80 & 3.037 & 1.902 \\
\hline 75 & .425 & .654 & 125 & .114 & 2.559 & 105 & 1.164 & 1.387 \\
\hline 95 & .453 & .373 & 140 & .048 & .154 & 145 & .076 & .108 \\
\hline $160^{*}$ & .006 & .060 & 220 & .010 & .164 & & & \\
\hline 170 & .014 & .011 & & & & & & \\
\hline 240 & .001 & .001 & & & & & & \\
\hline
\end{tabular}

* Average Values of 2 or more samples

+ Air Flow speeded up during sampling 
DWG. NOS. K/G-10-4366 K/G-80-436?

Table 3

SHIELDED METAL ARC (SMA) AREA SAMPLES

\begin{tabular}{|c|c|c|c|c|c|}
\hline \multicolumn{2}{|c|}{ PLATE WELDING } & \multicolumn{2}{|c|}{ GEOMETRIC SHAPE "DONUT" } & \multicolumn{2}{|c|}{ GEOMETRIC CYLINDER "TIN CAN" } \\
\hline AIR FLOW (fpm) & $\begin{array}{c}\mathrm{mg} / \mathrm{m}^{3} \\
\text { OF NICKEL }\end{array}$ & AIR FLOW (fpm) & $\begin{array}{c}\mathbf{m g} / \mathbf{m}^{3} \\
\text { OF NICKEL }\end{array}$ & AIR FLOW (fpm) & $\begin{array}{c}\mathrm{mg} / \mathrm{m}^{3} \\
\text { OF NICKEL }\end{array}$ \\
\hline $\begin{array}{r}75 \\
100 \\
160 \\
175 \\
185 \\
\therefore 200 \\
230 \\
300\end{array}$ & $\begin{array}{l}.965 \\
.228 \\
.001 \\
.001 \\
.005 \\
.003 \\
.010 \\
<.001\end{array}$ & $\begin{array}{c}20^{*} \\
85 \\
90 \\
110 \\
115 \\
160 \\
250\end{array}$ & $\begin{array}{l}.776 \\
.600 \\
.016 \\
.011 \\
.080 \\
.029 \\
.006\end{array}$ & $\begin{array}{c}63 \\
90 \\
110 \\
145+\end{array}$ & $\begin{array}{r}2.564 \\
.250 \\
.232 \\
.004\end{array}$ \\
\hline
\end{tabular}

Table 4

METAL INERT GAS (MIG) AREA SAMPLES

\begin{tabular}{|c|c|c|c|c|c|}
\hline \multicolumn{2}{|c|}{ PLATE WELDING } & \multicolumn{2}{|c|}{ GEOMETRIC SHAPE "DONUT" } & \multicolumn{2}{|c|}{ GEOMETRIC CYLINDER "TIN CAN" } \\
\hline AIR FLOW (fpm) & $\begin{array}{c}\mathbf{m g} / \mathbf{m}^{3} \\
\text { OF NICKEL }\end{array}$ & AIR FLOW (fpin) & $\begin{array}{c}\mathrm{mg} / \mathrm{m}^{3} \\
\text { OF NICKEL }\end{array}$ & AIR FLOW (fpm) & $\begin{array}{c}\mathrm{mg} / \mathrm{m}^{3} \\
\text { OF NICKEL }\end{array}$ \\
\hline $\begin{array}{r}20^{*} \\
75 \\
95 \\
160 \\
170 \\
240\end{array}$ & $\begin{array}{r}1.709 \\
.246 \\
.431 \\
.002 \\
.001 \\
.013\end{array}$ & $\begin{array}{r}20 \\
125 \\
140 \\
220\end{array}$ & $\begin{array}{r}3.014 \\
.789 \\
.028 \\
.011\end{array}$ & $\begin{array}{r}80 \\
105 \\
145\end{array}$ & $\begin{array}{r}1.990 \\
.951 \\
.025\end{array}$ \\
\hline
\end{tabular}

* Average of 2 or more samples.

+Air Flow speeded up during sampling. 
Table 5

\begin{tabular}{|c|c|c|c|c|}
\hline $\begin{array}{c}\text { TYPE OF WELDING } \\
\text { OPERATION }\end{array}$ & $\begin{array}{l}r^{2} \text { VALUE } \\
\text { INSIDE HELMET }\end{array}$ & $\begin{array}{l}\text { AIRFLOW IN FPM } \\
\text { NEEDED TO } \\
\text { CONTROL NICKEL } \\
\text { TO } 0.015 \mathrm{mg} / \mathrm{m}^{3} \\
\end{array}$ & $\begin{array}{c}r^{2} \text { VALUE } \\
\text { OUTSIDE HELMET }\end{array}$ & $\begin{array}{c}\text { AIRFLOW IN FPM } \\
\text { NEEDED TO } \\
\text { CONTROL NICKEL } \\
\text { TO } 0.015 \mathrm{mg} / \mathrm{m}^{3} \\
\end{array}$ \\
\hline SMA Flat Plate & 0.687 & 120 & 0.697 & 160 \\
\hline SMA Geometric "Donut" Shape & 0.746 & 140 & 0.482 & 270 \\
\hline SMA Geometric Cylinder & 0.925 & 145 & 0.802 & 175 \\
\hline MIG Flat Plate & 0.962 & 165 & 0.964 & 176 \\
\hline MIG Geometric "Donut" Shape & 0.979 & 195 & 0.586 & Off Scale \\
\hline MIG Geometric Cylinder & 0.981 & 175 & 0.918 & 192 \\
\hline
\end{tabular}


OWG. NO. K/G-40-4368

(u)

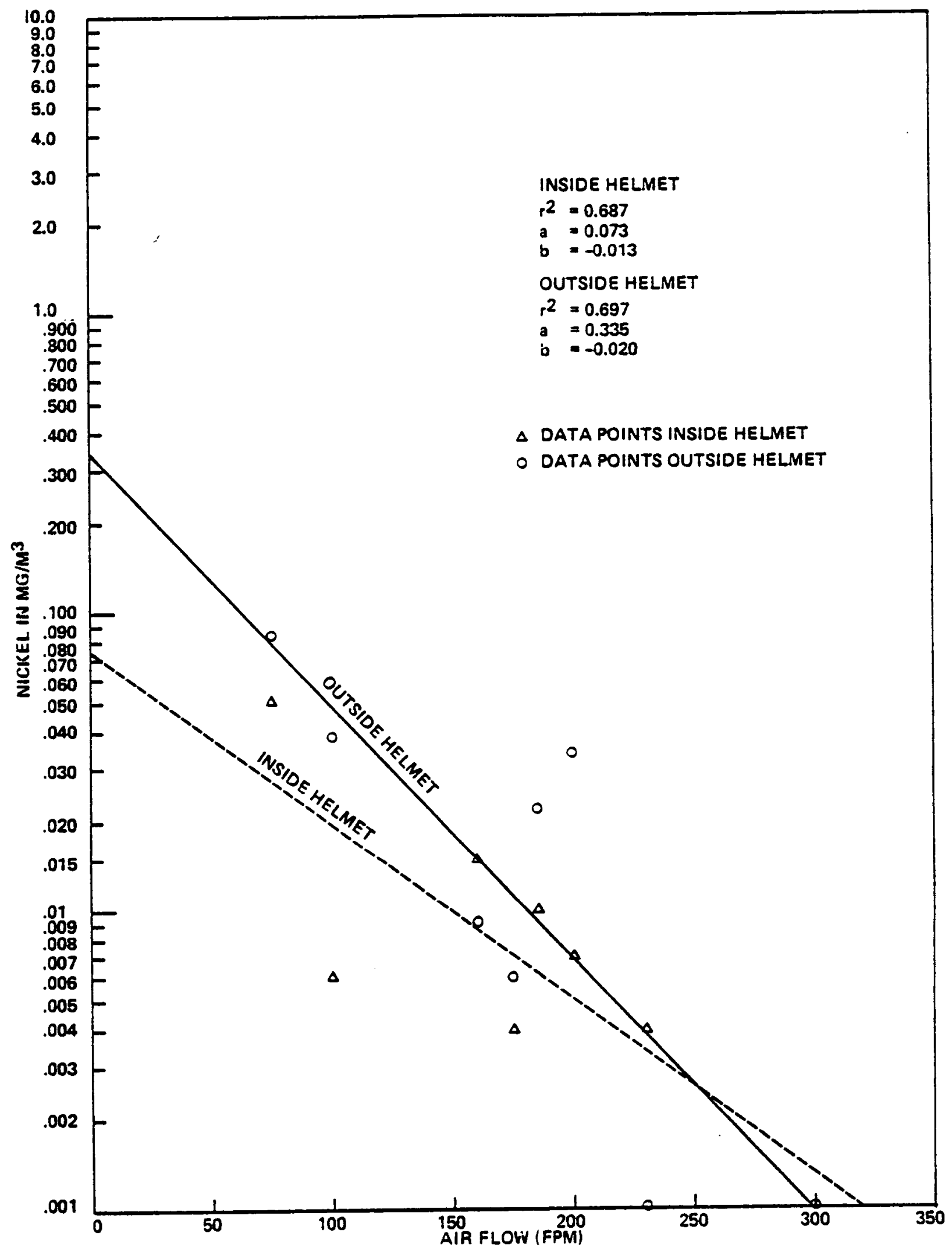

Figure 1

PLATE WELDING (SMA) 


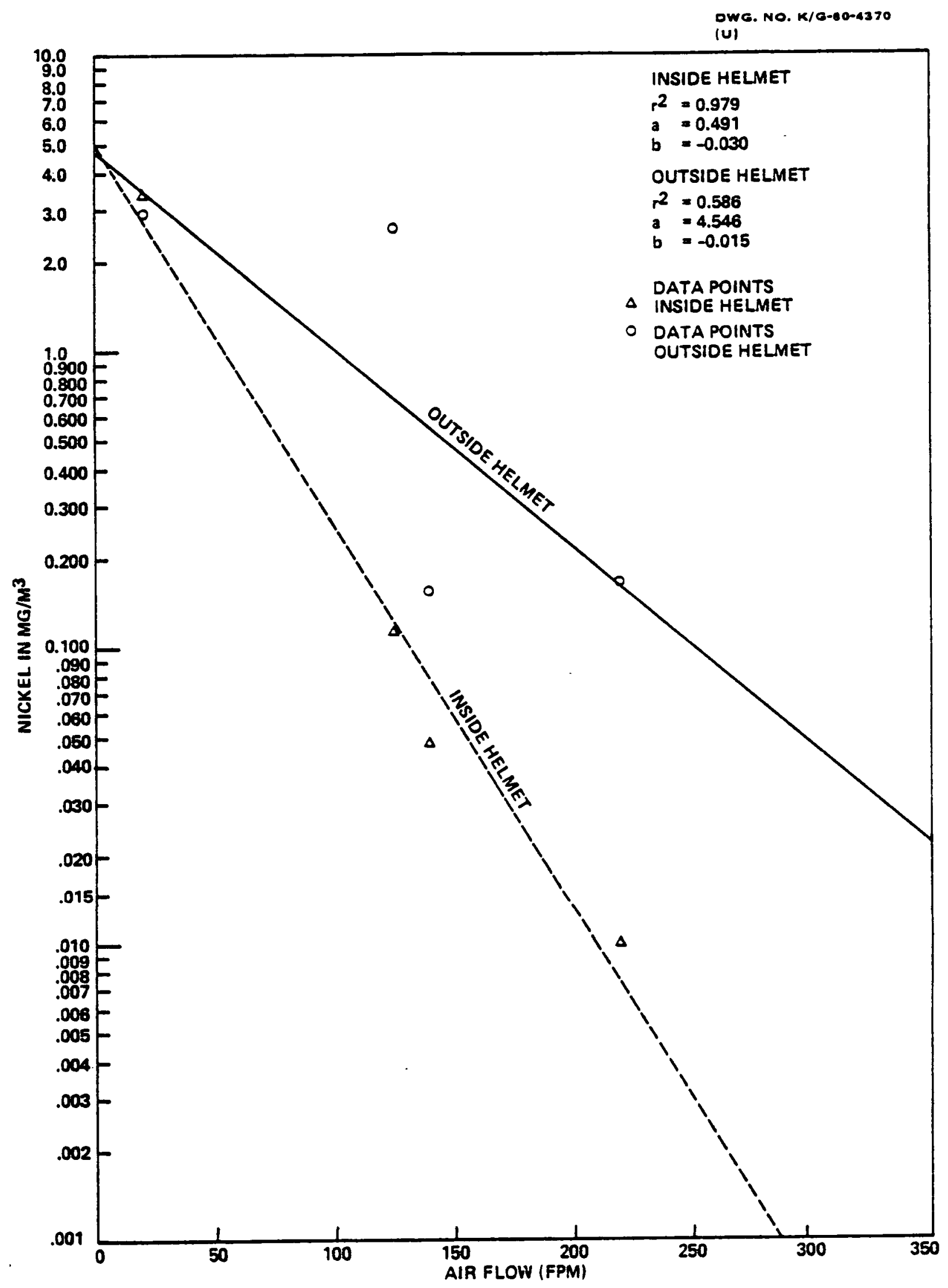

Figure 2

GEOMETRIC "DONUT" SHAPE (MIG) 


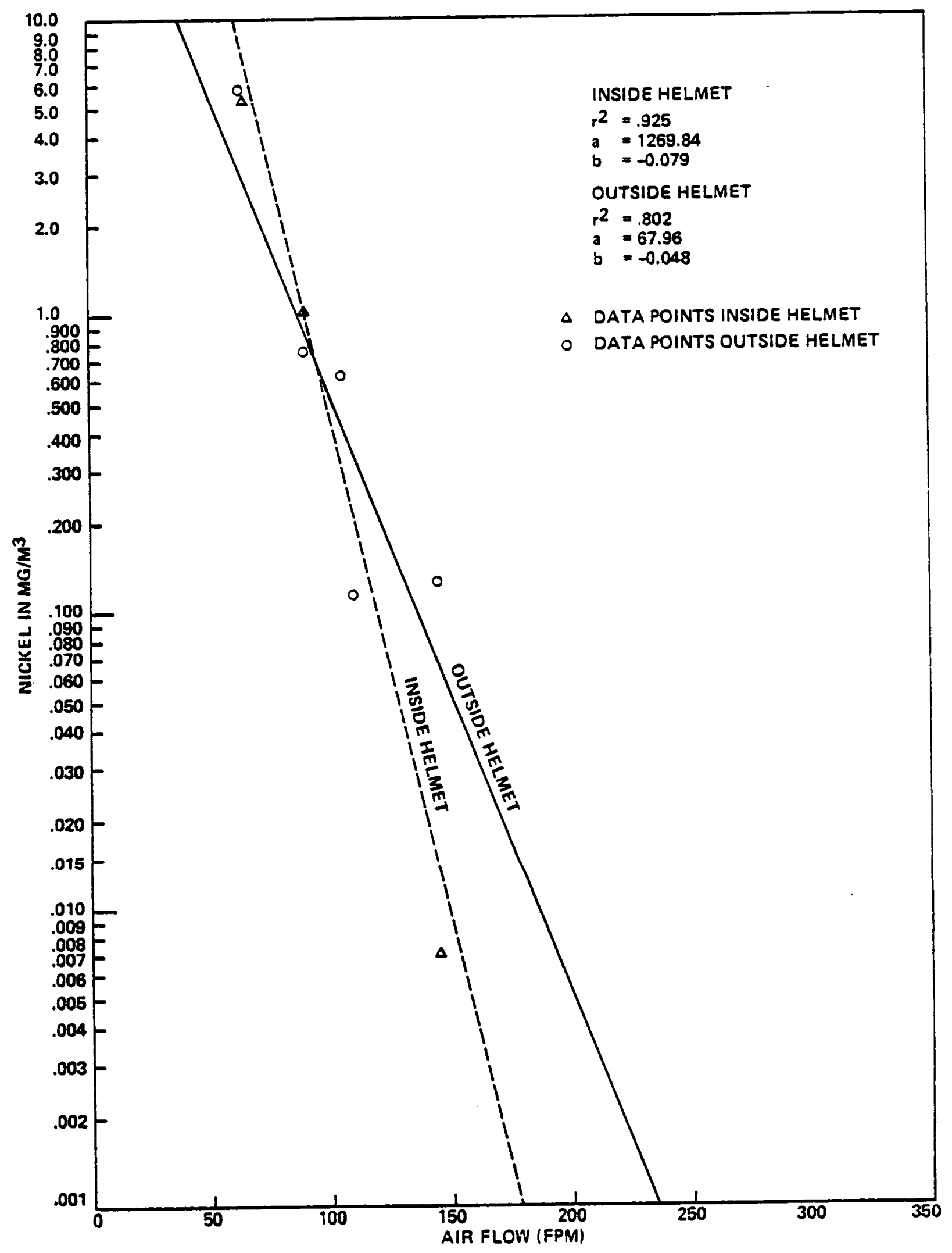

Figure 3

GEOMETRIC CYLINDER (SMA) 
OWG. MO. K/G-80-4372

(U)

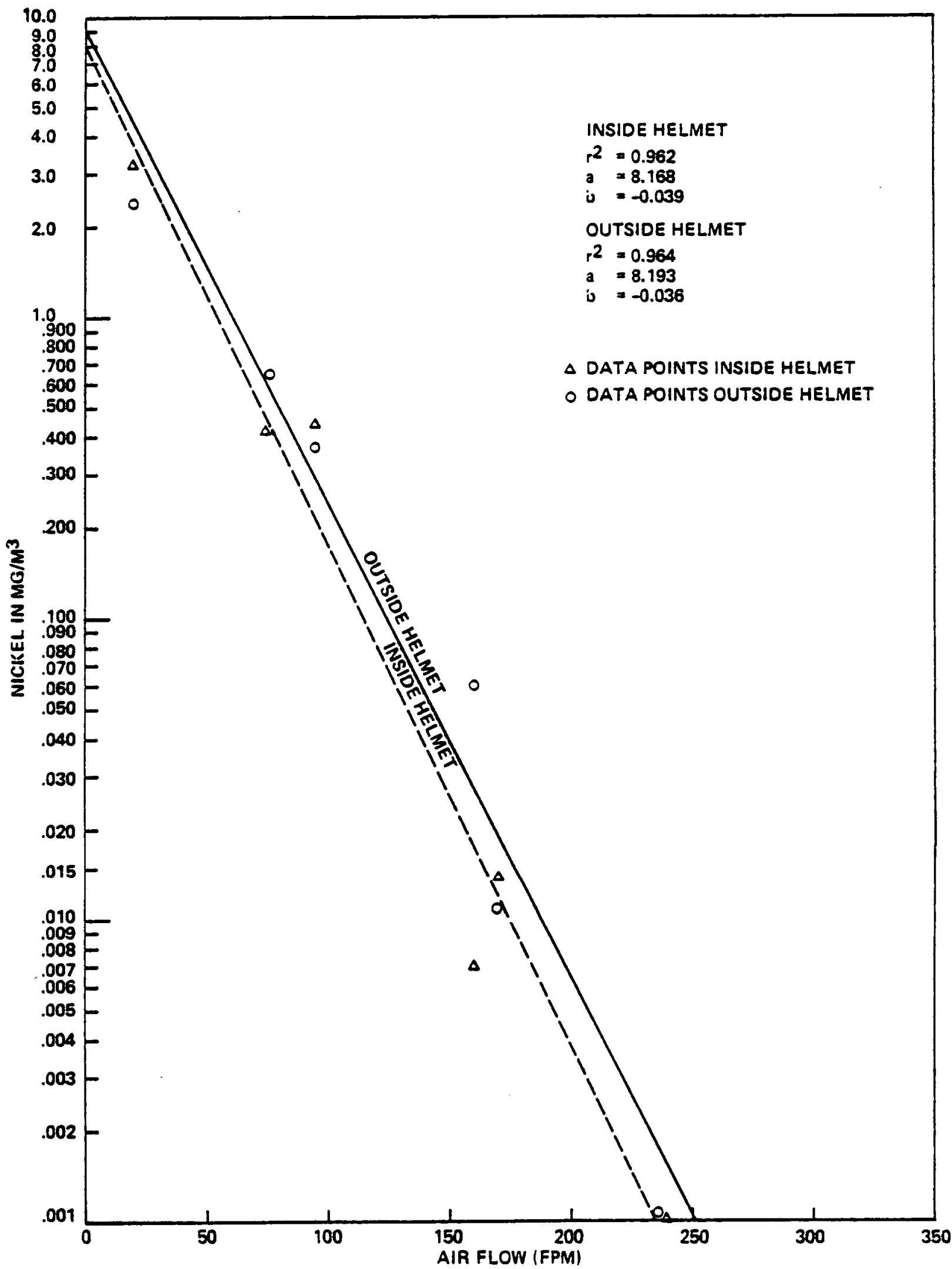

Figure 4

PLATE WELDING (MIG) 


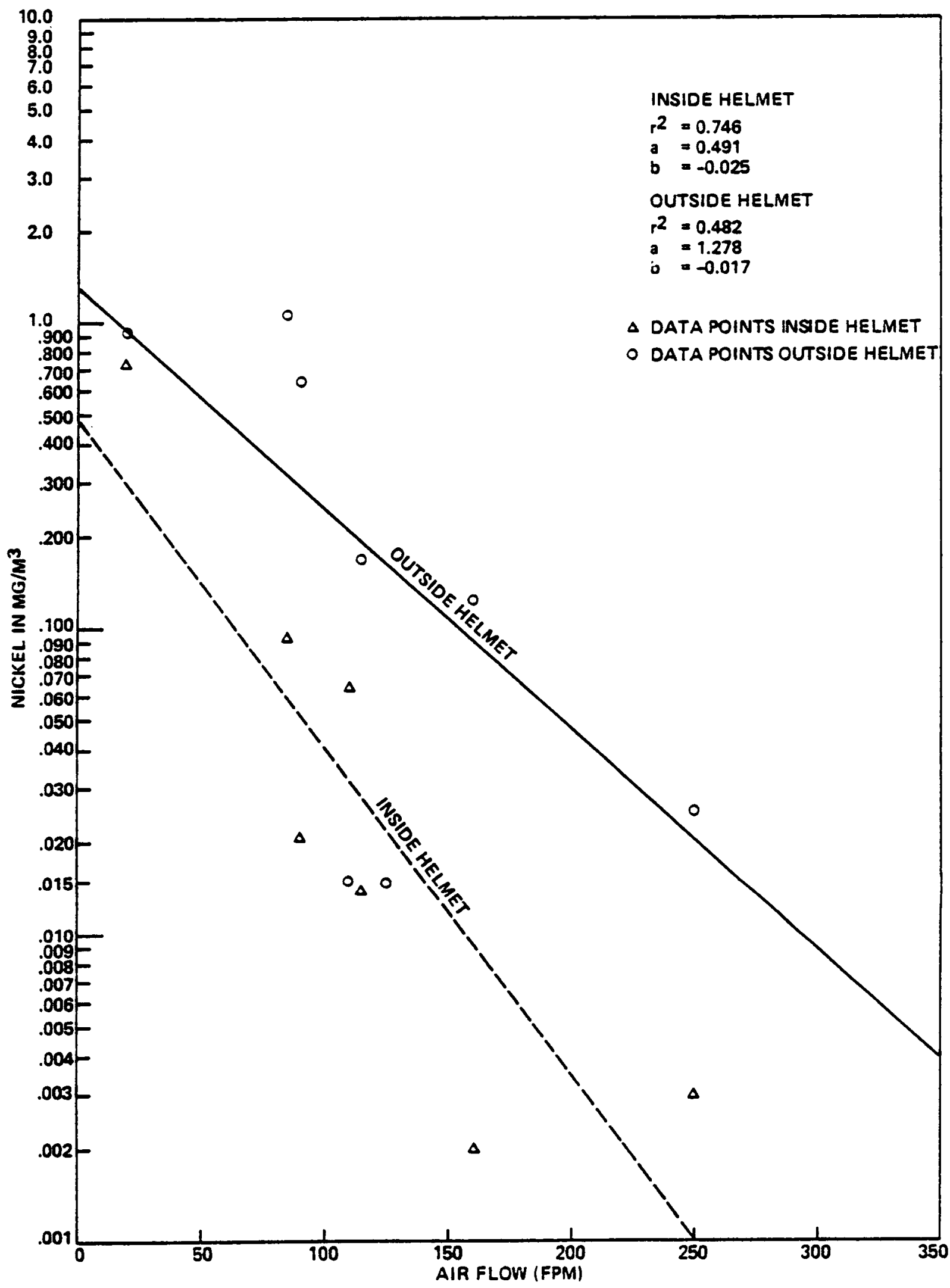

Figure 5

GEOMETRIC "DONUT" SHAPE (SMA) 
DWG. MO. K/G-10-4374

(U)

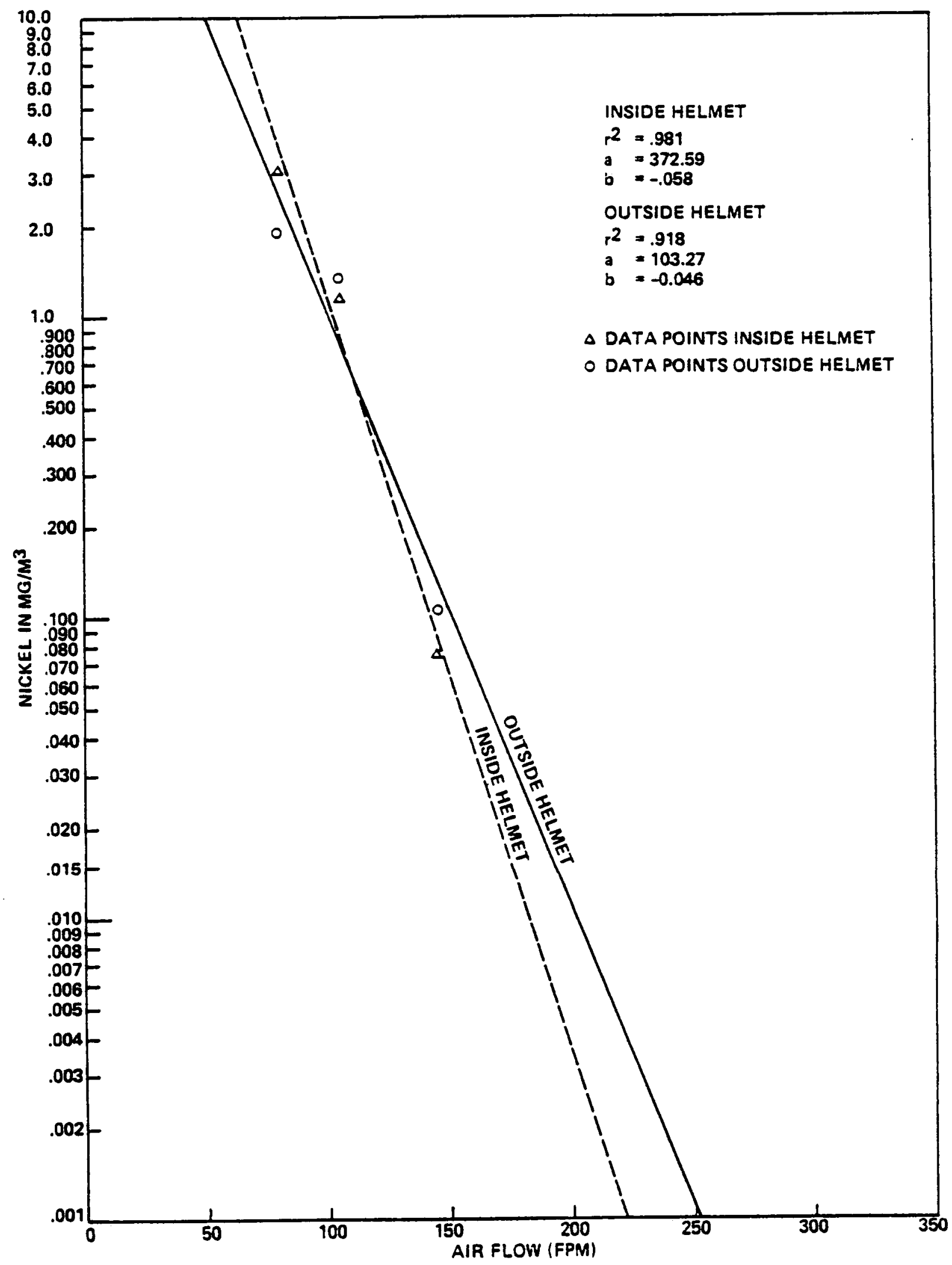

Figure 6

GEOMETRIC CYLINDER (MIG) 